OAK RIDGE NATIONAL LABORATORY
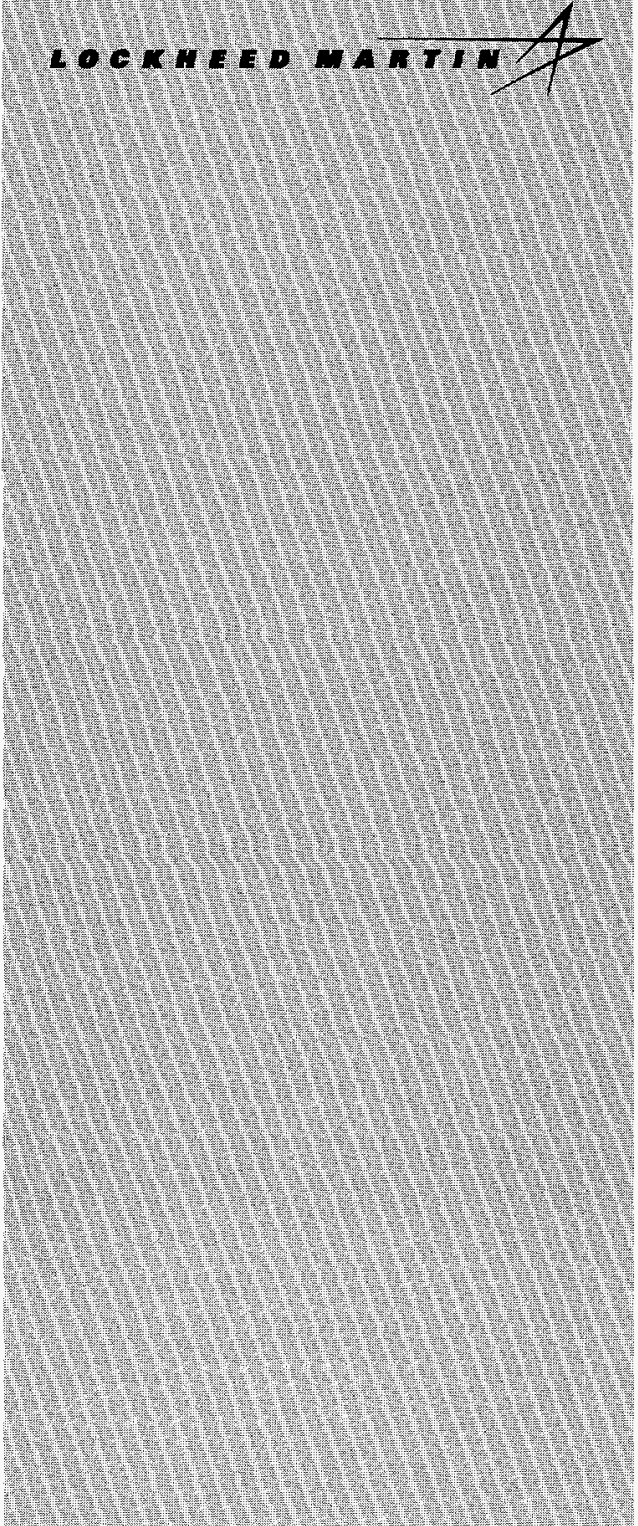

WANAGED AND OPERATED BY

LOCXHEED WARTN ENERGY RESEARCH CORPORATION FOB THE UNTEO STATES DEPARTIENT OF ENERGY

\section{Storage of Assemblies Containing Mixed-Oxide Fuel}

\author{
R. T. Primm III \\ J. C. Ryman \\ S. B. Ludwig
}

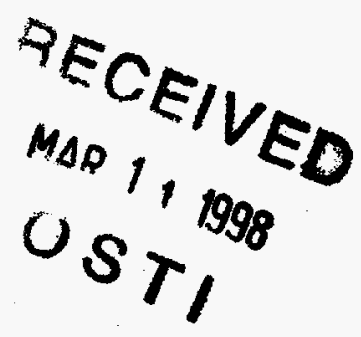


This report has been reproduced directly from the best available copy.

Available to DOE and DOE contractors from the Office of Scientific and Technical Information, P.O. Box 62, Oak Ridge, TN 37831; prices available from (423) 576-8401.

Available to the public from the National Technical Information Service, U.S. Department of Commerce, 5285 Port Royal Rd., Springfield, VA 22161.

This report was prepared as an account of work sponsored by an agency of the United States Government. Neither the United States Government nor any agency thereof, nor any of their employees, makes any warranty, express or implied, or assumes any legal liability or responsibility for the accuracy, completeness, or usefulness of any information, apparatus, product, or process disclosed, or represents that its use would not infringe privately owned rights. Reference herein to any specific commercial product, process, or service by trade name, trademark, manufacturer, or otherwise, does not necessarily constitute or imply its endorsement, recommendation, or favoring by the United States Government or any agency thereof. The views and opinions of authors expressed herein do not necessarily state or reflect those of the United States Government or any agency thereof. 


\section{DISCLAIMER}

Portions of this document may be illegible electronic image products. Images are produced from the best available original document. 
ORNL/TM-13424

Dist. Category UC-523

STORAGE OF ASSEMBLIES CONTAINING MIXED-OXIDE FUEL

\author{
R. T. Primm III \\ J. C. Ryman \\ S. B. Ludwig
}

Date Published: April 1997

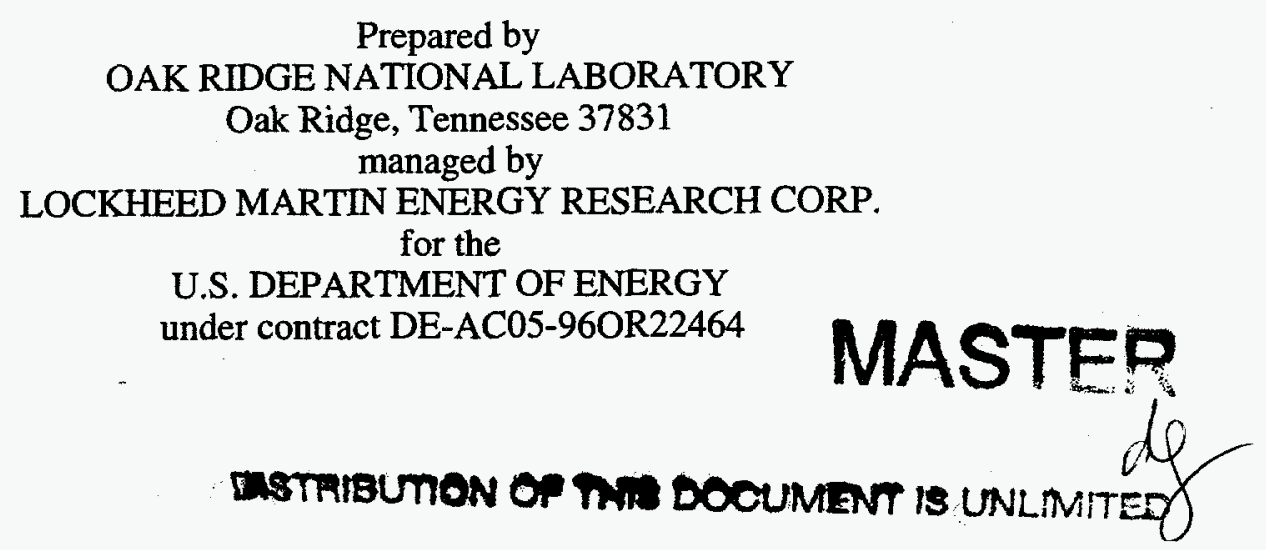




\section{Page Intentionally Blank}




\section{CONTENTS}

Page

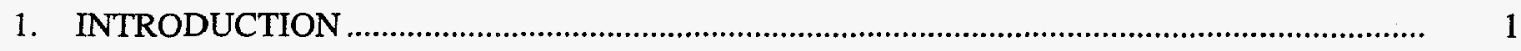

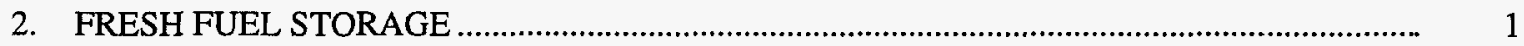

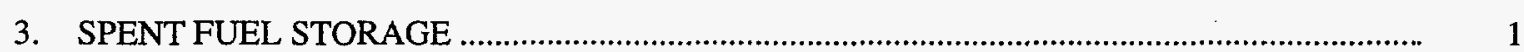

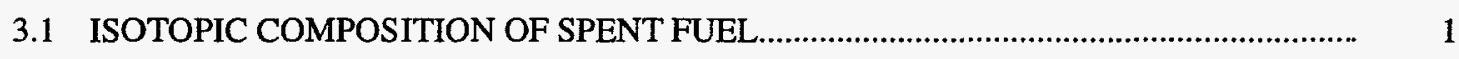

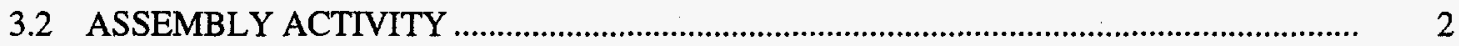

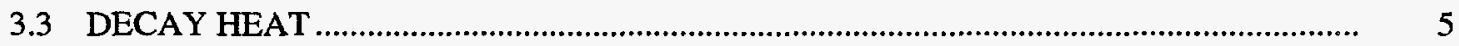

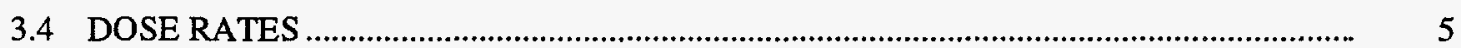

3.5 POTENTIAL INHALATION AND INGESTION HAZARDS .......................................... 5

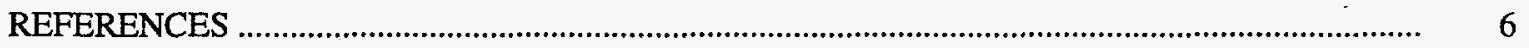


Page Intentionally Blank 


\section{PREFACE}

This document is one in a series of topical reports written in support of the U.S. Department of Energy's (DOE's) Program Acquisition Strategy for Obtaining Mixed-Oxide Fuel Fabrication and Reactor Irradiation Services (PAS) [formerly Procurement Implementation Plan for Acquisition of Mixed-Oxide Fuel Fabrication Services and Reactor Irradiation Services (PIP)]. This series of topical reports is intended to increase access to available information for parties interested in responding to PAS and the subsequent request for proposal. These topical reports address subjects relevant to DOE's strategy concerning disposition of surplus plutonium by irradiating mixed-oxide (MOX) fuel in existing, domestic commercial reactors. 


\section{INTRODUCTION}

Both fresh and spent mixed-oxide (MOX) assemblies exhibit physical characteristics that will necessitate additional measurements and analyses beyond those that are done for low-enriched uranium (LEU) assemblies. While none of these analyses or measurements require technological development, estimates for disposition costs and schedules must account for these factors. This report identifies those nuclear engineering analyses that will be required to demonstrate acceptability of MOX fuel assembly storage.

\section{FRESH FUEL STORAGE}

The reference fresh fuel storage scheme as documented in Ref. 1 is to construct a stand-alone, exreactor fuel storage vault. This vault is deemed necessary by the reactor vendors because of the perceived requirement of increased security associated with MOX fuel. The building is to serve as both temporary storage for fresh fuel and dry storage for spent fuel. If, indeed, the facility is to be designed for dry storage, regulatory requirements are available in Refs. 2 and 3.

Criticality safety calculations will be required for MOX fresh fuel storage. Reference 4 provides guidance on validation of criticality safety codes for application to transportation and storage. Although the decay heat generation in fresh MOX fuel will be significantly greater than for LEU fuel, engineered (forced) cooling systems should not be required. A mechanism for transportation of assemblies between the MOX storage facility and the reactor building must be devised, because none was specified in Ref. 1 .

The operators of the Tennessee Valley Authority's Bellefonte plant have expressed the opinion that, at their facility, a separate storage facility will not be required. Even if a separate facility is not required, it is likely that significant modifications to existing facilities would be required. In a recent visit to the Arkansas Nuclear One site, it was noted that in order to receive MOX assemblies transported via a safe, secure trailer (SST), it would be necessary to modify the fuel receiving facility and its administrative controls to provide the appropriate safeguards controls for the material in the receiving bay, thus removing the need to isolate the receiving bay from the refueling floor during fuel handling operations. As such, it would be necessary to fortify the receiving bay to Category I safeguards measures. Such modifications would also include construction of appropriate facilities to handle SST operations at the reactor. Some information regarding safeguards criteria can be found in Ref. 1.

Also for Arkansas Nuclear One, the fuel vault has only the capacity to hold a partial core. If a full core of new fuel is received, some will have to be moved into the spent fuel pool in advance of charging the reactor core. For MOX fuel, the spent fuel pool storage spacing may be insufficient for effective criticality control. This spacing would have to be reviewed prior to any such fuel receipt.

\section{SPENT FUEL STORAGE}

Regardless of whether the spent fuel is stored in a pool or in dry storage, nuclear engineering evaluations of the storage sites must consider criticality safety, radiation protection (shielding), decay heat generation, and potential radionuclide releases to the environment in the event of an accident. Analyses for each of these four areas will be facility and fuel cycle dependent. However, an estimate of the impact of substituting MOX fuel for LEU fuel has been calculated by J. C. Ryman at Oak Ridge National Laboratory. Based on the General Electric boiling-water reactor (BWR) MOX fuel design described in Ref. 1 (BWR-5) and an LEU fuel cycle designed to yield equivalent burnup ( $37.6 \mathrm{GWd} / \mathrm{MT}$ ), comparisons were made between MOX and LEU fuel cycles and are presented in subsequent tables.

\subsection{ISOTOPIC COMPOSITION OF SPENT FUEL}

Discharge spent fuel inventories for MOX and LEU fuels are shown in Table 1. Because an LEU assembly is charged with much more ${ }^{235} \mathrm{U}$, it burns more ${ }^{235} \mathrm{U}$; it will, therefore, contain more ${ }^{236} \mathrm{U}$ and 
Table 1. Nuclides of interest for criticality safety

\begin{tabular}{|c|c|c|c|}
\hline \multirow[b]{2}{*}{ Nuclide } & \multicolumn{2}{|c|}{ Quantity of discharge per assembly $(\mathrm{g})$} & \multirow[b]{2}{*}{$\begin{array}{c}\text { Ratio of MOX } \\
\text { to LEU }\end{array}$} \\
\hline & MOX & LEU & \\
\hline $16 \mathrm{O}$ & $4.72 \times 10^{4}$ & $4.84 \times 10^{4}$ & 0.975 \\
\hline $95 \mathrm{Mo}$ & $1.25 \times 10^{2}$ & $1.53 \times 10^{2}$ & 0.817 \\
\hline${ }^{101} \mathrm{Ru}$ & $1.63 \times 10^{2}$ & $1.60 \times 10^{2}$ & 1.02 \\
\hline${ }^{99} \mathrm{Tc}$ & $1.52 \times 10^{2}$ & $1.59 \times 10^{2}$ & 0.956 \\
\hline${ }^{103} \mathrm{Rh}$ & $1.23 \times 10^{2}$ & $8.82 \times 10^{1}$ & 1.39 \\
\hline${ }^{109} \mathrm{Ag}$ & $3.71 \times 10^{1}$ & $1.90 \times 10^{1}$ & 1.95 \\
\hline${ }^{131} \mathrm{Xe}$ & $9.42 \times 10^{1}$ & $8.74 \times 10^{1}$ & 1.08 \\
\hline${ }^{133} \mathrm{Cs}$ & $2.24 \times 10^{2}$ & $2.30 \times 10^{2}$ & 0.974 \\
\hline $143 \mathrm{Nd}$ & $1.38 \times 10^{2}$ & $1.57 \times 10^{2}$ & 0.879 \\
\hline $145 \mathrm{Nd}$ & $1.16 \times 10^{2}$ & $1.37 \times 10^{2}$ & 0.847 \\
\hline $147 \mathrm{Sm}$ & $2.08 \times 10^{1}$ & $2.24 \times 10^{1}$ & 0.929 \\
\hline${ }^{149} \mathrm{Sm}$ & 0.444 & 0.398 & 1.12 \\
\hline${ }^{150} \mathrm{Sm}$ & $6.17 \times 10^{1}$ & $6.12 \times 10^{1}$ & 1.01 \\
\hline${ }^{151} \mathrm{Sm}$ & 3.39 & 2.83 & 1.20 \\
\hline $152 \mathrm{Sm}$ & $3.11 \times 10^{1}$ & $2.61 \times 10^{1}$ & 1.19 \\
\hline${ }^{151} \mathrm{Eu}$ & $6.90 \times 10^{-3}$ & $5.02 \times 10^{-3}$ & 1.37 \\
\hline${ }^{153} \mathrm{Eu}$ & $2.87 \times 10^{1}$ & $2.27 \times 10^{1}$ & 1.26 \\
\hline${ }^{154} \mathrm{Eu}$ & $1.15 \times 10^{1}$ & 8.72 & 1.32 \\
\hline${ }^{155} \mathrm{Gd}$ & 0.139 & 0.0330 & 4.21 \\
\hline${ }^{233} \mathrm{U}$ & $3.64 \times 10^{-5}$ & $5.01 \times 10^{-4}$ & 0.0727 \\
\hline${ }^{234} U$ & 0.457 & $2.87 \times 10^{1}$ & 0.0159 \\
\hline $235 \mathrm{U}$ & $1.04 \times 10^{2}$ & $1.31 \times 10^{3}$ & 0.0794 \\
\hline${ }^{236} \mathrm{U}$ & $4.39 \times 10^{1}$ & $8.16 \times 10^{2}$ & 0.0538 \\
\hline${ }^{238} \mathrm{U}$ & $1.68 \times 10^{5}$ & $1.72 \times 10^{5}$ & 0.977 \\
\hline${ }^{237} \mathrm{~Np}$ & $3.08 \times 10^{1}$ & $9.93 \times 10^{1}$ & 0.310 \\
\hline $238 \mathrm{Pu}$ & $3.66 \times 10^{1}$ & $4.23 \times 10^{1}$ & 0.865 \\
\hline${ }^{239} \mathrm{Pu}$ & $1.40 \times 10^{3}$ & $9.81 \times 10^{2}$ & 1.43 \\
\hline $240 \mathrm{Pu}$ & $1.16 \times 10^{3}$ & $4.49 \times 10^{2}$ & 2.58 \\
\hline${ }^{241} \mathrm{Pu}$ & $5.57 \times 10^{2}$ & $2.64 \times 10^{2}$ & 2.11 \\
\hline${ }^{242} \mathrm{Pu}$ & $2.43 \times 10^{2}$ & $1.11 \times 10^{2}$ & 2.19 \\
\hline${ }^{241} \mathrm{Am}$ & $4.20 \times 10^{1}$ & $1.49 \times 10^{1}$ & 2.82 \\
\hline $242 \mathrm{~m} A m$ & 1.17 & 0.414 & 2.83 \\
\hline${ }^{243} \mathrm{Am}$ & $5.97 \times 10^{1}$ & $2.68 \times 10^{1}$ & 2.23 \\
\hline${ }^{245} \mathrm{Cm}$ & 0.974 & $0.349 \times 10^{-3}$ & 2.79 \\
\hline
\end{tabular}

${ }^{237} \mathrm{~Np}$ at discharge than a MOX assembly. At long decay times, the amounts of ${ }^{235} \mathrm{U},{ }^{236} \mathrm{U}$, and ${ }^{237} \mathrm{~Np}$ increase significantly in the MOX assembly as compared with the LEU assembly because of the alpha decay of ${ }^{239} \mathrm{Pu},{ }^{240} \mathrm{Pu}$, and ${ }^{241} \mathrm{Am}$ (which arises from the decay of ${ }^{241} \mathrm{Pu}$ ); the ${ }^{237} \mathrm{~Np}$ becomes absolutely greater in the MOX assembly.

The MOX assembly has about 1.8 times as much plutonium at discharge as the LEU assembly. All of the americium and curium isotopes show higher concentrations at discharge in the MOX fuel relative to the LEU fuel.

\subsection{ASSEMBLY ACTIVITY}

Table 2 gives discharge activities for nuclides of interest in both MOX and LEU assemblies. Most of the contribution to activity comes from actinides and fission products, with light elements contributing $1 \%$ or less. 
Table 2. Discharge activities for BWR-5 MOX and LEU assemblies

\begin{tabular}{|c|c|c|c|}
\hline Nuclide & $\begin{array}{l}\text { Activity in MOX } \\
\text { per assembly } \\
\text { (Ci) }\end{array}$ & $\begin{array}{l}\text { Activity in LEU } \\
\text { per assembly } \\
\text { (Ci) }\end{array}$ & $\begin{array}{l}\text { Ratio of MOX to } \\
\text { LEU }\end{array}$ \\
\hline${ }^{3} \mathrm{H}$ & $1.01 \times 10^{2}$ & $9.41 \times 10^{1}$ & 1.07 \\
\hline${ }^{14} \mathrm{C}$ & $3.17 \times 10^{-2}$ & $4.07 \times 10^{-2}$ & $7.79 \times 10^{-1}$ \\
\hline${ }^{58} \mathrm{Co}$ & $3.94 \times 10^{2}$ & $3.83 \times 10^{2}$ & 1.03 \\
\hline${ }^{60} \mathrm{Co}$ & $5.51 \times 10^{2}$ & $5.49 \times 10^{2}$ & 1.00 \\
\hline${ }^{85} \mathrm{Kr}$ & $9.77 \times 10^{2}$ & $1.65 \times 10^{3}$ & $5.92 \times 10^{-1}$ \\
\hline $85 \mathrm{~m}_{\mathrm{Kr}}$ & $1.86 \times 10^{4}$ & $2.74 \times 10^{4}$ & $6.79 \times 10^{-1}$ \\
\hline${ }^{87} \mathrm{Kr}$ & $3.63 \times 10^{4}$ & $5.44 \times 10^{4}$ & $6.67 \times 10^{-1}$ \\
\hline${ }^{88} \mathrm{Kr}$ & $4.85 \times 10^{4}$ & $7.49 \times 10^{4}$ & $6.48 \times 10^{-1}$ \\
\hline${ }^{86} \mathrm{Rb}$ & $1.39 \times 10^{2}$ & $2.42 \times 10^{2}$ & $5.74 \times 10^{-1}$ \\
\hline${ }^{89} \mathrm{Sr}$ & $5.26 \times 10^{4}$ & $8.51 \times 10^{4}$ & $6.18 \times 10^{-1}$ \\
\hline${ }^{90} \mathrm{Sr}$ & $7.55 \times 10^{3}$ & $1.48 \times 10^{4}$ & $5.10 \times 10^{-1}$ \\
\hline${ }^{91} \mathrm{Sr}$ & $9.13 \times 10^{4}$ & $1.33 \times 10^{5}$ & $6.86 \times 10^{-1}$ \\
\hline${ }^{92} \mathrm{Sr}$ & $1.08 \times 10^{5}$ & $1.45 \times 10^{5}$ & $7.45 \times 10^{-1}$ \\
\hline${ }^{90} \mathrm{Y}$ & $8.53 \times 10^{3}$ & $1.61 \times 10^{4}$ & $5.30 \times 10^{-1}$ \\
\hline${ }^{91} \mathrm{Y}$ & $7.40 \times 10^{4}$ & $1.09 \times 10^{5}$ & $6.79 \times 10^{-1}$ \\
\hline${ }^{92} \mathrm{Y}$ & $1.08 \times 10^{5}$ & $1.46 \times 10^{5}$ & $7.40 \times 10^{-1}$ \\
\hline${ }^{93} \mathrm{Y}$ & $9.07 \times 10^{4}$ & $1.14 \times 10^{5}$ & $7.96 \times 10^{-1}$ \\
\hline${ }^{95} \mathrm{Zr}$ & $1.47 \times 10^{5}$ & $1.70 \times 10^{5}$ & $8.65 \times 10^{-1}$ \\
\hline${ }^{97} \mathrm{Zr}$ & $2.04 \times 10^{5}$ & $2.20 \times 10^{5}$ & $9.27 \times 10^{-1}$ \\
\hline${ }^{95} \mathrm{Nb}$ & $1.22 \times 10^{5}$ & $1.41 \times 10^{5}$ & $8.65 \times 10^{-1}$ \\
\hline${ }^{99} \mathrm{Mo}$ & $2.22 \times 10^{5}$ & $2.31 \times 10^{5}$ & $9.61 \times 10^{-1}$ \\
\hline $99 \mathrm{~m}$ Tc & $1.95 \times 10^{5}$ & $2.04 \times 10^{5}$ & $9.56 \times 10^{-1}$ \\
\hline${ }^{103} \mathrm{Ru}$ & $2.11 \times 10^{5}$ & $1.87 \times 10^{5}$ & 1.13 \\
\hline${ }^{105} \mathrm{Ru}$ & $1.93 \times 10^{5}$ & $1.53 \times 10^{5}$ & 1.26 \\
\hline${ }^{106} \mathrm{Ru}$ & $1.15 \times 10^{5}$ & $7.52 \times 10^{4}$ & 1.53 \\
\hline${ }^{105} \mathrm{Rh}$ & $1.86 \times 10^{5}$ & $1.46 \times 10^{5}$ & 1.27 \\
\hline${ }^{127} \mathrm{Sb}$ & $1.35 \times 10^{4}$ & $1.18 \times 10^{4}$ & 1.14 \\
\hline${ }^{127} \mathrm{Te}$ & $1.28 \times 10^{4}$ & $1.11 \times 10^{4}$ & 1.15 \\
\hline $127 \mathrm{~m} \mathrm{Te}$ & $1.74 \times 10^{3}$ & $1.46 \times 10^{3}$ & 1.19 \\
\hline${ }^{129} \mathrm{Te}$ & $4.08 \times 10^{4}$ & $3.90 \times 10^{4}$ & 1.05 \\
\hline${ }^{129} \mathrm{~m} \mathrm{Te}$ & $7.74 \times 10^{3}$ & $7.32 \times 10^{3}$ & 1.06 \\
\hline${ }^{132} \mathrm{Te}$ & $1.76 \times 10^{5}$ & $1.79 \times 10^{5}$ & $9.83 \times 10^{-1}$ \\
\hline${ }^{131}{ }_{I}$ & $1.24 \times 10^{5}$ & $1.25 \times 10^{5}$ & $9.92 \times 10^{-1}$ \\
\hline${ }^{132} \mathrm{I}$ & $1.80 \times 10^{5}$ & $1.83 \times 10^{5}$ & $9.84 \times 10^{-1}$ \\
\hline $133_{I}$ & $2.45 \times 10^{5}$ & $2.55 \times 10^{5}$ & $9.61 \times 10^{-1}$ \\
\hline${ }^{134_{I}}$ & $2.63 \times 10^{5}$ & $2.79 \times 10^{5}$ & $9.43 \times 10^{-1}$ \\
\hline $135_{I}$ & $2.37 \times 10^{5}$ & $2.43 \times 10^{5}$ & $9.75 \times 10^{-1}$ \\
\hline $131 \mathrm{~m}_{\mathrm{Xe}}$ & $1.40 \times 10^{3}$ & $1.40 \times 10^{3}$ & 1.00 \\
\hline $133 \mathrm{~m}_{\mathrm{Xe}}$ & $7.99 \times 10^{3}$ & $8.14 \times 10^{3}$ & $9.82 \times 10^{-1}$ \\
\hline${ }^{133} \mathrm{Xe}$ & $2.36 \times 10^{5}$ & $2.45 \times 10^{5}$ & $9.63 \times 10^{-1}$ \\
\hline${ }^{135} \mathrm{Xe}$ & $8.25 \times 10^{4}$ & $7.61 \times 10^{4}$ & 1.08 \\
\hline${ }^{134} \mathrm{Cs}$ & $2.65 \times 10^{4}$ & $2.74 \times 10^{4}$ & $9.67 \times 10^{-1}$ \\
\hline${ }^{136} \mathrm{Cs}$ & $1.10 \times 10^{4}$ & $9.06 \times 10^{3}$ & 1.21 \\
\hline
\end{tabular}


Table 2. (continued)

\begin{tabular}{|c|c|c|c|}
\hline Nuclide & $\begin{array}{l}\text { Activity in MOX } \\
\text { per assembly } \\
\text { (Ci) }\end{array}$ & $\begin{array}{l}\text { Activity in LEU } \\
\text { per assembly } \\
\text { (Ci) }\end{array}$ & $\begin{array}{l}\text { Ratio of MOX } \\
\text { to LEU }\end{array}$ \\
\hline${ }^{137} \mathrm{Cs}$ & $2.14 \times 10^{4}$ & $2.17 \times 10^{4}$ & $9.86 \times 10^{-1}$ \\
\hline${ }^{139} \mathrm{Ba}$ & $2.05 \times 10^{5}$ & $2.21 \times 10^{5}$ & $9.28 \times 10^{-1}$ \\
\hline $140 \mathrm{Ba}$ & $2.08 \times 10^{5}$ & $2.21 \times 10^{5}$ & $9.41 \times 10^{-1}$ \\
\hline${ }^{140} \mathrm{La}$ & $2.21 \times 10^{5}$ & $2.36 \times 10^{5}$ & $9.36 \times 10^{-1}$ \\
\hline${ }^{141} \mathrm{La}$ & $1.86 \times 10^{5}$ & $2.01 \times 10^{5}$ & $9.25 \times 10^{-1}$ \\
\hline${ }^{142} \mathrm{La}$ & $1.78 \times 10^{5}$ & $1.96 \times 10^{5}$ & $9.08 \times 10^{-1}$ \\
\hline${ }^{141} \mathrm{Ce}$ & $1.72 \times 10^{5}$ & $1.86 \times 10^{5}$ & $9.25 \times 10^{-1}$ \\
\hline${ }^{143} \mathrm{Ce}$ & $1.63 \times 10^{5}$ & $1.85 \times 10^{5}$ & $8.81 \times 10^{-1}$ \\
\hline${ }^{144} \mathrm{Ce}$ & $1.04 \times 10^{5}$ & $1.24 \times 10^{5}$ & $8.39 \times 10^{-1}$ \\
\hline${ }^{143} \mathrm{Pr}$ & $1.57 \times 10^{5}$ & $1.78 \times 10^{5}$ & $8.82 \times 10^{-1}$ \\
\hline${ }^{147} \mathrm{Nd}$ & $7.85 \times 10^{4}$ & $8.26 \times 10^{4}$ & $9.50 \times 10^{-1}$ \\
\hline${ }^{237} \mathrm{U}$ & $2.97 \times 10^{4}$ & $1.18 \times 10^{5}$ & $2.52 \times 10^{-1}$ \\
\hline${ }^{239} \mathrm{U}$ & $2.61 \times 10^{6}$ & $2.74 \times 10^{6}$ & $9.53 \times 10^{-1}$ \\
\hline${ }^{237} \mathrm{~Np}$ & $2.17 \times 10^{-2}$ & $7.00 \times 10^{-2}$ & $3.10 \times 10^{-1}$ \\
\hline${ }^{238} \mathrm{~Np}$ & $1.75 \times 10^{4}$ & $6.03 \times 10^{4}$ & $2.90 \times 10^{-1}$ \\
\hline${ }^{239} \mathrm{~Np}$ & $2.60 \times 10^{6}$ & $2.74 \times 10^{6}$ & $9.49 \times 10^{-1}$ \\
\hline${ }^{238} \mathrm{Pu}$ & $6.28 \times 10^{2}$ & $7.25 \times 10^{2}$ & $8.66 \times 10^{-1}$ \\
\hline${ }^{239} \mathrm{Pu}$ & $8.72 \times 10^{1}$ & $6.09 \times 10^{1}$ & 1.43 \\
\hline $240 \mathrm{Pu}$ & $2.63 \times 10^{2}$ & $1.02 \times 10^{2}$ & 2.58 \\
\hline${ }^{239} \mathrm{U}$ & $2.61 \times 10^{6}$ & $2.74 \times 10^{6}$ & $9.53 \times 10^{-1}$ \\
\hline${ }^{237} \mathrm{~Np}$ & $2.17 \times 10^{-2}$ & $7.00 \times 10^{-2}$ & $3.10 \times 10^{-1}$ \\
\hline $238 \mathrm{~Np}$ & $1.75 \times 10^{4}$ & $6.03 \times 10^{4}$ & $2.90 \times 10^{-1}$ \\
\hline${ }^{239} \mathrm{~Np}$ & $2.60 \times 10^{6}$ & $2.74 \times 10^{6}$ & $9.49 \times 10^{-1}$ \\
\hline${ }^{238} \mathrm{Pu}$ & $6.28 \times 10^{2}$ & $7.25 \times 10^{2}$ & $8.66 \times 10^{-1}$ \\
\hline${ }^{239} \mathrm{Pu}$ & $8.72 \times 10^{1}$ & $6.09 \times 10^{1}$ & 1.43 \\
\hline $240 \mathrm{Pu}$ & $2.63 \times 10^{2}$ & $1.02 \times 10^{2}$ & 2.58 \\
\hline${ }^{241} \mathrm{Pu}$ & $5.76 \times 10^{4}$ & $2.73 \times 10^{4}$ & 2.11 \\
\hline${ }^{241} \mathrm{Am}$ & $1.44 \times 10^{2}$ & $5.11 \times 10^{1}$ & 2.82 \\
\hline${ }^{242} \mathrm{Cm}$ & $3.22 \times 10^{4}$ & $1.25 \times 10^{4}$ & 2.58 \\
\hline${ }^{244} \mathrm{Cm}$ & $1.63 \times 10^{3}$ & $6.69 \times 10^{2}$ & 2.44 \\
\hline
\end{tabular}

The activity from structural materials is comparable for both assembly types. If everything else were equal, the light-element contribution to activity would just be proportional to burnup. The amount of light elements per metric ton of heavy metal (MTHM) is the same for both assemblies, and the burnup is the same. However, there is 0.183 MTHM in the LEU assembly and 0.176 MTHM in the MOX assembly, which causes slightly more light-element activity in the LEU assembly. A major contributor to lightelement activity is ${ }^{60} \mathrm{Co}$. The final amount of ${ }^{60} \mathrm{Co}$ depends on the initial amount of ${ }^{59} \mathrm{Co}$ in the assembly.

Activities for many, but not all, fission products are comparable, with the LEU assembly having somewhat higher values (4 to 5\%) than the MOX assembly. These ratios of fission product activity (MOX to LEU) are just about the same as the ratio of heavy metal content $(0.176 \mathrm{MTHM}$ to $0.183 \mathrm{MTHM}=$ 0.962) for the MOX and LEU assemblies because the burnups are equal. The slight differences from the 
value of 0.962 are caused by differences in the fission yields of the uranium and plutonium mixtures in the two assemblies.

The actinide activity is slightly greater at discharge (4\%) for the LEU assembly because of higher activities for the short-lived nuclide ${ }^{239} \mathrm{~Np}$ and its daughter ${ }^{239} \mathrm{U}$. For decay times from 1 year until 10,000 years, the larger quantities of long-lived actinides in the MOX assembly cause its actinide activity to be greater by about a factor of 2. Beyond that decay time, the ratio of MOX to LEU actinide activity slowly decreases to a value of about 1.1 at 250,000 years.

\subsection{DECAY HEAT}

The actinide decay heats for MOX and LEU assemblies are comparable at discharge, but are consistently larger for the MOX assembly at long decay times. The fission product decay heat is generally less in the MOX assembly for decay times less than 300 years and greater past that time. The total decay heat at discharge is about $6 \%$ larger for the LEU assembly because it comes primarily from fission products at that time. For cooling times of 1 year or greater, the total is greater for the MOX assembly and is comprised principally of actinide decay heat for times greater than 100 years.

\subsection{DOSE RATES}

The neutron dose rate from the MOX assembly is about 2.5 times greater than that from the LEU assembly. The greater dose from the MOX assembly is caused by the greater amounts of curium and americium nuclides in that fuel as compared with the LEU assembly. The gamma dose rates from both assemblies are comparable (ratios from 1.07 to 0.95 ) from discharge until 300 years following discharge (see Table 3). Neutron dose rates are $1 / 100,000$ th of the gamma dose rate at discharge but are $1 / 200$ th of the gamma dose rate at 300 years after discharge.

Table 3. Gamma dose rate $1 \mathrm{~m}$ from a bare BWR-5 assembly at the axial midplane

\begin{tabular}{lll}
\hline & \multicolumn{2}{c}{ Dose rate $\left(\mathrm{rem} \mathrm{h}^{-1}\right)$} \\
\cline { 2 - 3 } Time after discharge & \multicolumn{1}{c}{ MOX } & \multicolumn{1}{c}{ LEU } \\
\hline At discharge & $1.55 \times 10^{6}$ & $1.66 \times 10^{6}$ \\
1 day & $1.39 \times 10^{5}$ & $1.43 \times 10^{5}$ \\
1 year & 5280 & 4890 \\
5 years & 1680 & 1610 \\
10 years & 968 & 936 \\
100 years & 85.1 & 85.6 \\
300 years & 0.927 & 0.882 \\
\hline
\end{tabular}

\subsection{POTENTIAL INHALATION AND INGESTION HAZARDS}

Calculations performed using the ORIGEN-S program 5 give a rough estimate of the potential hazards from inhalation and ingestion of radionuclides in the fuel assemblies. These potential hazards are quantified as the amount of air or water necessary to dilute the amount of radionuclides to the radioactivity concentration guide limits of the pre-1993 version of Title 10 of the Code of Federal Regulations Part 20. It must be emphasized that these are potential hazards because thorough pathway and dosimetry analy ses would be necessary to estimate the doses and risks for particular exposure incidents. Broadly speaking, the MOX assembly is potentially more hazardous for inhalation because of the greater quantities of alpha-emitting 
and bone-seeking actinides. The potential ingestion hazard is slightly greater for the nuclides from the LEU assembly because of the importance of light-element and fission product nuclides.

\section{REFERENCES}

1. S. R. Greene et al., FMDP Reactor Alternative Summary Report, Vol. 1-Existing LWR Alternative, ORNL/TM-13275/V1, Lockheed Martin Energy Research, Oak Ridge National Laboratory, October 7, 1996.

2. Standard Review Plan for Dry Cask Storage Systems, NUREG-1536, U.S. Nuclear Regulatory Commission, January 1997.

3. M. G. Raddatz and M. D. Walters, Information Handbook on Independent Spent Fuel Storage Installations, NUREG-1571, Office of Nuclear Material Safety and Safeguards, U.S. Nuclear Regulatory Commission, December 1996.

4. J. J. Lichtenwalter et al., Criticality Benchmark Guide for Light-Water-Reactor Fuel in Transportation and Storage Packages, NUREG/CR-6361 (ORNL/TM-13211), Office of Nuclear Material Safety and Safeguards, U.S. Nuclear Regulatory Commission, January 1997.

5. SCALE-A Modular Code System for Performing Standardized Computer Analyses for Licensing Evaluation, NUREG/CR-0200 (ORNL/NUREG/CSD-2/R4), Vols. 1-3, Rev. 4, Lockheed Martin Energy Research Corp., Oak Ridge National Laboratory, Radiation Shielding Information Center, CCC-545 Version 4.3, April 1997. 
ORNL/TM-13424

Dist. Category UC-523

\section{INTERNAL DISTRIBUTION}

1. S. L. Byerly

2. E. C. Fox

3. S. R. Greene

4. S. B. Ludwig

5. G. T. Mays

6. G. E. Michaels

7. D. G. O'Connor

8-12. R. T. Primm III
13. P. L. Rittenhouse

14. J. C. Ryan

15. C. C. Southmayd

16. D. J. Spellman

17. D. L. Williams, Jr.

18. Central Research Library

19-20. ORNL Laboratory Records (OSTI)

21. ORNL Laboratory Records-RC

\section{EXTERNAL DISTRIBUTION}

22. D. J. Nulton, U.S. Department of Energy, MD-4, Forrestal Building, Room 6G-050, 1000 Independence Avenue SW, Washington, DC 20585.

23-27. P. T. Rhoads, U.S. Department of Energy, MD-3, Forrestal Building, Room 6G-050, 1000 Independence Avenue SW, Washington, DC 20585.

28. J. J. Buksa, Los Alamos National Laboratory, P.O. Box 1663, MS-F628, Los Alamos, NM 87545.

29. T. Barr, U.S. Department of Energy, EPG, Argonne National Laboratory, 9800 South Cass Avenue, Argonne, IL 60439.

\section{WWW DISTRIBUTION}

The FMDP Web site, with a list of other relevant topical reports, is located at the following URL:

http://www.ornl.gov/etd/FMDP/fmdpproc.htm 